\title{
Analysis of Global Trends in the Development of Retail Payment Services in the Global Economy
}

\author{
Elizaveta Yakimova ${ }^{1, *}$, and Irina Ershova ${ }^{2}$ \\ ${ }^{1}$ Assistant Professor, Department of Finance and Credit, Southwest State University, Kursk, Russia \\ ${ }^{2}$ Professor, Department of Finance and Credit, Southwest State University, Kursk, Russia
}

\begin{abstract}
.
Research background: The relevance of the study is confirmed by the fact that large banks of developed countries in the globalized economy receive commission income from settlement transactions at a level comparable to interest income from credit and deposit operations. This significantly increases the profitability of the banking business, reduces risks, makes banks more stable. Thus, payment services to the population in the context of globalization and competition between banks is one of the important business areas.

Purpose of the article: Analysis and assessment of development trends of retail payment services in different countries in the context of globalization. To achieve this goal, the following tasks were solved: segments of national payment systems were studied; revealed the main world innovations in the development of retail payment services; The analysis of the main retail payment services in various countries, which characterize the degree of development of the banking business in the context of globalization.

Methods: The methodological basis of the study was a systematic approach. In the process, such methods as analysis and synthesis, grouping and analogy methods, a comparative historical approach, economic and mathematical modeling were used.

Findings \& Value added: As a result of this study, various types of major world innovations in the development of retail payment services were reasonably identified, and based on an analysis of global trends in the development of retail payment services, promising directions for their development were proposed.
\end{abstract}

Keywords: payment services; globalization; credit card

JEL Classification: $G 210 ; G 280 ; F 020$

\footnotetext{
*Corresponding author: ershovairgen@yandex.ru
} 


\section{Introduction}

Over the past three decades, the modernization of national payment systems has come to figure prominently in financial sector reform programs in many countries. Today, in most countries of the world, two closely related payment segments of national payment systems (NPS) have finally formed, such as (Figure 1):

1) the segment of large and urgent transfers of funds, associated mainly with interbank settlements, as well as with the settlement of transactions in the stock and foreign exchange markets. They are called wholesale payments or large value payments;

2) a segment of mass, relatively small in terms of the amount of payments in consumer and business turnover - retail payments $[1,2]$.

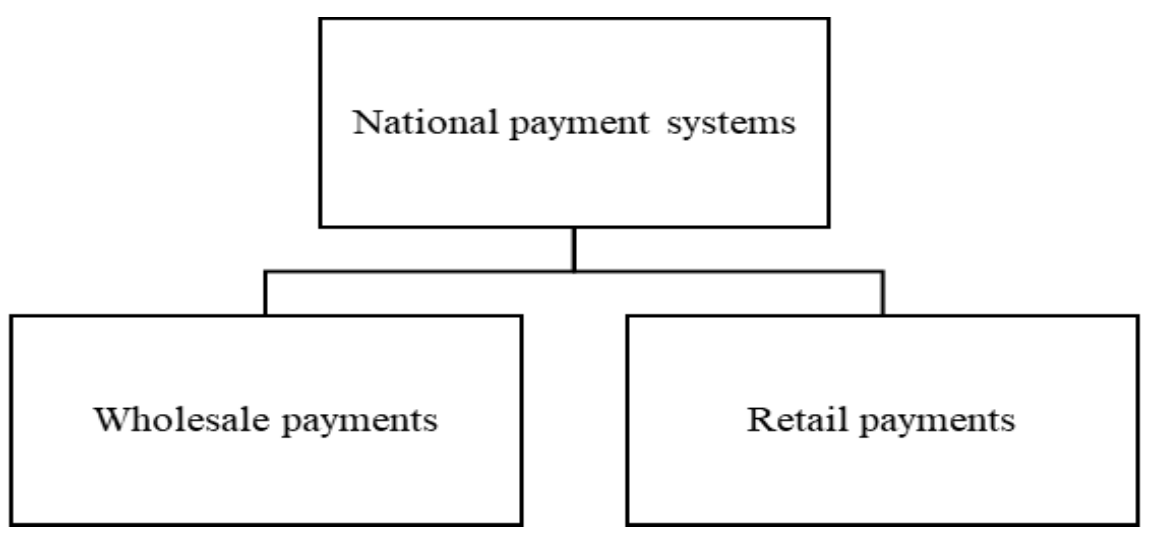

Fig. 1. Segments of national payment systems.

Currently, in the segment of retail payments, simultaneously with the use of traditional payment instruments, a wide range of the latest tools for transferring funds (mobile banking, cryptocurrencies, etc.) is being actively introduced, which creates the preconditions for increasing attention from the state, represented by the financial regulator, to the development process this segment.

The analysis of the economic literature showed that the segment of retail payments has been studied less fully and in detail in comparison with the wholesale, starting with the identification of retail payments and its features, and ending with assessing the role of innovative payment instruments in improving the quality and availability of payment services for the population.

However, over the past few years, there has been an increase in interest, both from business and from the government (in the person of the financial regulator), in retail payments and retail payment systems, recognizing that such systems are very important because they ensure the efficient execution of daily payments. population, and accordingly contribute to the growth of the national economy.

For example, Moody's analysts have calculated that increased growth in bank card use allowed the global economy to receive an additional \$ 296 billion in the period from 2011 to 2015 , which in relative terms is $+0.1 \%$ of global GDP. Thanks to a $0.01 \%$ increase in the share of using bank cards, real consumption grew by $2.3 \%$ over the same period. This means that payments by bank cards accounted for $0.4 \%$ of the growth in consumption, which increased the average growth of jobs to 2.6 million in the period 2011-2015. [3]. 


\section{Methodology and Results}

Over the past three decades, modernization of the payments sector has come to figure prominently in financial sector reform programs in many countries. As a rule, central banks played a leading role in its implementation, stimulating the financial activity of businesses and the population, which led to the development of not only wholesale, but also retail payment systems that provide payment services to the population. Recognition of their importance for the national economy is typical for all countries. The interest of state institutions in the development of payment services based on negotiated deals through the development and implementation of programs to increase their availability has become especially noticeable.

The main global innovations in the development of retail payment services include the following:

- User identification solutions, as the ability of the payment service provider (PSP) to accurately identify its existing and potential new customers is central to the provision of any electronic payment service (especially innovative) for transferring funds.

- Today in the world, according to the World Bank, about 2.4 billion people do not have an official identification (ID), including children under 14 years of age, whose birth was not registered by many women in poor rural areas of Africa and Asia [11, c ... 169].

- Poor or no identification mechanisms for individuals can make it difficult to access the RPA. In addition, PSPs are becoming more and more demanding in terms of anti-money laundering procedures and the implementation of "know your customer" requirements. Thus, individuals who do not have an identifier required to open an account can be excluded for this reason from the payment service. In this regard, a modern and reliable identification system (ID) is required for the provision of payment services in various sectors of the economy, including health care, social security, financial services and transportation.

- In most low- and middle-income countries, national ID systems are underdeveloped. Countries including sub-Saharan Africa, for example, do not have an official identification protocol, and at least $55 \%$ of the inhabitants of these countries do not have a personal ID.

As a positive example of solving this problem, we can cite the experience of India in developing the Aadhaar codifier in order to provide its citizens with unique identifiers. As of April 2015, 818 million Aadhaar numbers (currently almost 1 billion people) and associated payment cards had been issued, and coverage of identified adults increased to 93\%. Information containing demographic data and photographs is provided by the special identification authority of India (in electronic form) to prevent money laundering. Aadhaar facilitates the delivery of social benefits through direct transfers to recipients' bank accounts. The government has already begun routing transfers of gas subsidies, as well as social benefits through the banking network using the Aadhaar platform $[4,5]$.

Noteworthy is the experience of creating a Single Payment Area (SEPA) in Europe in order to overcome technological and market barriers between countries in order to create a single market for retail payments in euros, in which cross-border payments are as fast, secure and efficient as in-country payments. SEPA includes 34 European countries (28 EU member states plus some non-EU countries). The next phase of SEPA was implemented in August 2014. Since then, the existing national credit transfer and direct debit schemes have been replaced by SEPA instruments, thus providing the basis for an integrated European retail payments market. In general, SEPA has expanded the payment services market and made them more accessible. This development is expected to enable organizations involved 
in retail payments to achieve economies of scale and compete with the quality of their services and is therefore expected to contribute to financial inclusion.

The next area is the provision of retail payment services through national mail. Post offices provide financial services in many countries, usually through an extensive branch network. For example, in Turkey, a publicly owned post office with more than 4,300 branches across the country has become a supplier to the domestic retail payments market. It offers a wide range of services, including accepting payments, conducting domestic and international money transfers. In addition, post office customers can deposit and withdraw money at offices across the country, and can also deposit money into anyone else's account. The bill payment service was originally launched in 1999 in partnership with Garanti Bank. Pensions and unemployment benefits are paid through post offices. Recipients can either withdraw funds or send them to another account. Since 2011, recipients have been provided with PTTcards, which allow them to make payments at ATMs. As of the end of 2016, 1.6 million retirement cards, out of a total of 3.7 million PTTcards, were specially issued to receive retirement benefits. Since 2013, the Department of Family and Social Affairs has started using prepaid PTTcards that can be used for cash withdrawals and payments. Recipients can register their phone number and receive an SMS notification when receiving funds. PTT Bank offers these prepaid cards free of any commission from the cardholder. Recipients are given such a card when they first come to the post office for money.

As of the end of 2014, there were 596.5 thousand prepaid cards issued. Since 2009, financial services have been provided to customers around the clock through ATM devices called "PTTmatic". At the end of 2016, 2,126 PTTmatic devices were installed. PTT Bank also offers agent services for other banks and insurance companies. Currently, the issue of increasing the number of its services is being discussed by mail with the Central Bank of the Republic of Turkey, the Banking Supervision and Regulation Agency and other regulators of the financial market [6,7].

Thus, the post office is an important infrastructure element of the NPS, expanding access to payment services to the population, while using such tools as payment cards and prepaid cards, using agency business models.

The experience of Brazil is very interesting, which significantly increased the availability of transactions throughout the country through the use of bank correspondent agents. The development of the current model began over 20 years ago, and its stability and continuous improvement are a constant part of the program of the Central Bank of Brazil. Today, agent correspondent points operate in all municipalities in Brazil, and these offices now account for more than half of all financial service access points in the country. The share of municipalities with more than five service points per 10,000 adults has grown from $18 \%$ in 2000 to $94 \%$ in 2010 . As of the end of February 2015 , the total number of PPU agents was 343,741 . These agents provide clients with easier access to RPA and other operations, including accepting deposits and withdrawing cash, saving customers time and cost of travel to the bank branch to complete these operations. Some banks have also created simplified settlements with reduced account opening requirements that can be opened and accessed through agents.

The analysis of the world experience in the development of RPU showed that the direction of development of innovative ways of providing settlement payment services using mobile devices has the best prospects. This statement is confirmed in the Global Findex report [50], which highlights the important role of innovative payment service delivery. For example, between 2011 and 2014, the proportion of adults with account holders increased from $51 \%$ to $62 \%$, a trend driven by a 13 percentage point increase in the number of account holders in developing countries and the important role modern technology plays. Particularly in sub-Saharan Africa, the use of money in mobile accounts is helping to rapidly improve access to financial services and improve their quality. 
According to the State of the Industry 2013: Mobile Financial Services for the Unbanked report, 2.5 billion people in low-income countries are unbanked. In addition, more than 1 billion people. are underserved but already have access to mobile phones with which they can use financial services [8-10].

One of the pilot projects in this area is M-Pesa in Kenya. Unfortunately, attempts to replicate it in other African countries have been unsuccessful, which means that there is no universal approach.

The next wave of more advanced mobile banking is currently expected: microfinanceonly mobile, mobile insurance, and the development of mobile financial institutions. For example Equity Bank in Kenya, which has been licensed to operate as a Mobile Virtual Network Operator. Equity Bank was founded in 1984 as a mortgage institution - Equity Building Society, then it transformed into a microfinance organization, and finally - turned into a typical commercial bank (now it is a universal trans-African bank, part of the Equity Bank Group holding, from 9, 2 million customers, present in Kenya, Tanzania, Uganda, Rwanda and South Sudan) [11-13].

In our view, in the future, the evolution of mobile technologies will blur the boundaries that separate telecommunications companies from financial institutions. Research shows a positive trend in mobile penetration. As the telecom industry continues to expand, mobile money transfer is now available in most developing countries, according to State of the Industry 2013: Mobile Financial Services for the Unbanked.

The next important area of development of RPU is P2P money transfers. The global volume of remittances amounted to $\$ 586$ billion in 2015, and reached \$ 636 million in 2017.But even in the European Union, only $42 \%$ of individuals used a financial institution for money transfers, $9.3 \%$ used the services of traditional money transfer operators. In developing countries, $15 \%$ of adults reported sending money to relatives or friends living in another part of the country, and 19\% received money in the past 12 months. Overall, 26\% of adults reported having either sent or received a money order in the past year. Domestic remittances are especially important in sub-Saharan Africa, where $48 \%$ of adults reported remittances sent or received $[14,15]$.

Sending and receiving remittances domestically occurs through a variety of channels, and includes making payments through a financial institution and using a mobile phone, and may involve the use of either transaction accounts or without opening an account. A third digital payment channel involves the use of a money transfer operator such as Western Union.

An important distinction between the types of electronic payments for money transfers is the criterion for sending through an account or without using an account. Money transfers are considered sent or received through an account if the respondent either had an account with a financial institution and reported sending or receiving a money transfer through a financial institution, or has a mobile money account and reported sending or receiving a money transfer through a mobile phone.

Many financial institutions and mobile payment service providers also offer over the counter (OTC) money transfers. For example, in Kenya and Tanzania, mobile payments are the most common way to send and receive money transfers. Among the $53 \%$ of adults in Kenya who reported sending remittances in $2014,90 \%$ did so using a mobile phone, $71 \%$ through a mobile money account, and the rest through OTC. Mobile phone transfers are becoming more common than the use of cash in most East African countries, as mobile money was introduced in these countries as a way to make domestic money transfers between urban and rural areas more convenient and efficient. 


\section{Discussion and Conclusions}

Thus, the analysis of global trends in the development of retail payment services has revealed such promising areas of their development as:

- development of payer identification and standardization in the payment industry;

- $\quad$ provision of retail payment services through post offices, payment agents;

- transferring funds without opening an account using mobile devices.

The analysis showed that over the past five years, the volume of mobile financial services has grown significantly in the world, which has contributed to the increased access of the poor to financial services. At the same time, rapidly advancing financial technologies pose a challenge for regulators in supporting cross-border payments around the world, especially in relation to combating money laundering, terrorist financing, fraud and other financial crimes.

\section{References}

1. Campbell, J.W., Tobin, I. (2015). Identification and trust in public organizations: A communicative approach. Public Management Review, 8(17), 1065-1084.

2. Tobin, I., Campbell, J.W. (2015). Identification and trust in public organizations a communicative approach. Public Management Review, 8(17), 1065-1084.

3. Tobin, I., Campbell, J.W., Hyunkukb, L. (2016). At the expense of others: Altruistic helping behaviour, performance management and transformational leadership. Public Management Review, 6(18), 795-818.

4. Morev, M. V., Kaminskiy V S., (2015). Public administration at the present stage of development of the Russian society. Sotsiologicheskie Issledovaniya, 10, 39.

5. Trampusch Christine (2015). The financialisation of sovereign debt: An institutional analysis of the reforms in German public debt management. German Politics, (2)24, 119-13.

6. Vertakova, Yu. V., Polozhentseva, Yu. S, Klevtsova, M. G. (2015). Investment mechanism of stimulation of cluster initiatives in the region. International Multidisciplinary Scientific Conference of Social Sciences and Arts SGEM Conference Proceedings: Political Sciences, Law, Finance, Economics and Tourism. Volume II: Finance, Economics and Tourism (pp. 771-779). Albena, Bulgaria.

7. Zhelyuk, T. L. (2010). Modernization of management system for long-term development of economy. Actual Problems of Economics, 105, 55-61.

8. Ershova, E., Ershova, I., Kolmykova, T., Devyatilova, A. (2019). The formation of a management system of electronic state and municipal services of the region. Proceedings of the 33rd International Business Information Management Association Conference, IBIMA 2019: Education Excellence and Innovation Management through Vision 2020 (pp. 7319-7326).

9. Ershova, I., Belyaeva, O., Obukhova, A. (2019). Investment in human capital education under the digital economy. Економічний часопис-XXI, (11-12), 69-77.

10. Rajskaya, M. V., Sagdeeva, A. A., Panteleeva, Yu. V., Malysheva, T. V., Ershova, I. G. (2019). Differentiated approach problems to innovative development management in russian regions. Humanities and Social Sciences Reviews, 7(4), 1262-1268.

11. Deviatilova, A., Ershova, I., Kvashnina, D., Sevryukova, L. (2016). Economic features of human migration. Editor Khalid S. Soliman Vision 2020: Innovation Management, Development Sustainability, and Competitive Economic Growth. 
Proceedings of the 28th International Business Information Management Association Conference (pp. 2249-2258).

12. Zaikanov, V. G., Minakova, T. B., Buldakova, E. V. (2015). Principles of GIS support of geoenvironmental mapping at a regional level. Water Resources, 7, (42), 970-974.

13. Kharchenko, E., Garbuz, I. (2016). Mechanisms of national economy and its regions adaptation to the conditions of integration to the world economy. Економічнии часопис-XXI, 3-4-1(157), 28-31.

14. Kolmykova, T., Emelyanov, S., Merzlyakova, E. (2017). Research of innovative potential of the region. Journal of Applied Engineering Science, 15(3). 276-279.

15. Belyaeva, E., Svetovtseva, T. (2016). Main trends of factoring market development at present economic conditions. Економічний часопис-XXI, 3-4-1(157). 65-67. 